\title{
Systematic prompting the new physiological and morphological, biological responses of modified metabolic induction process of Calendula officinalis $L$ under heat stress with couple of supplementary nutritional applications as safety of floriculture crops
}

waseem ahmed ( $\nabla$ waseemuaf12@gmail.com )

horticulture https://orcid.org/0000-0001-5658-6643

Rafia Azmant

$\mathrm{KU}$

Abdul Qayyum

Agro

Ayaz Mehmood

SSMU: Shanghai Jiao Tong University School of Medicine

Rasheed Ahmed

SS

\section{Research}

Keywords: Biometric, Calendula officinalis, Fertilization, Nitrogen, Phosphorus, yield

Posted Date: January 13th, 2021

DOI: https://doi.org/10.21203/rs.3.rs-141817/v1

License: (c) (i) This work is licensed under a Creative Commons Attribution 4.0 International License. Read Full License 


\section{Abstract \\ Purpose}

the objective of study to modified the metabolism of Calendula officinalis L. under heat stress couple with $\mathrm{N}$ and $\mathrm{P}$ application in two years of study.

\section{Methods}

the trail was conducted during peak summer season (months of May, June, and July) couple with different levels of $\mathrm{N}$ \& $\mathrm{P}$ application to monitor the quality and quantity characterization of marigold (Calendula officinalis $\mathrm{L}$.). The traits of three doses of $\mathrm{N}$ and $\mathrm{P}\left(0.6 \mathrm{~g}, 0.9 \mathrm{~g}\right.$, and $\left.0.8 \mathrm{~g}, 1^{-1} \mathrm{~g}\right)$ given to Calendula officinalis L.) to display the vegetative, reproductive, physiological parameters such as Malondialdehyde (MDA), Chlorophyll contents, Lipid Peroxidation Assay in leaves, Li and K contents, phytochemicals and nitrogen and phosphorus used efficacy

\section{Results}

showed that maximum values of Malondialdehyde (MDA), Chlorophylls, Lipid Peroxidation Assay in leaves observed followed by the alteration in Li and $\mathrm{K}$ measured in the month of May, June with slight differences July. The phytochemicals like total phenolic contents $(84.41 \mathrm{mg} \mathrm{GAE} / \mathrm{g})$, total antioxidants (36.3\% DPPH), total carotenoids and total flavonoids contents $(16.2$ and $0.9 \mathrm{mg} / 100 \mathrm{~g}$ ) were measured by $0.9 \mathrm{~g}$ of Nitrogen application and followed by $1 \mathrm{~g}$ of Phosphorus in both years of study. The respirational changes were observed in the higher rate of $\mathrm{P}$ levels. The liner changes of $\mathrm{N}$ and $\mathrm{P}$ rates showed some fluctuation in heat stress months.

\section{Conclusions}

It was concluded that the higher doses of both $\mathrm{N}$ and $\mathrm{P}$ fertilizers were effective in controlling the heat stress and mentioned the quality of florets by various induction and biological active process.

\section{Introduction}

Horticultural crops play a vital role in international trade and getting incentive in our country for as source of earing (Khan, 2001). The floriculture crops had impacts on the development of business in all over the world through their highly demands values (Khan, 2001). Medicinal and ornamental plant like Calendula officinalis L, contained significant bioactive compounds (Pérez Gutiérrez et al., 2006). belongs to family Asteraceae (Khan, 2001) although its origin is west Asia and Mediterranean of the world (Mozafariyan, 2003) but also cultivated in 17th century as an herbal medicine in Europe followed by its cultivation in growing areas of Germany, Czech Republic, Slovakia, Austria and Switzer Land, Hungary and recently in Egypt and Syria due to its significance (Paul et al., 2002). Calendula officinalis $\mathrm{L}$, is the rich resource of essential oil, triterpene saponins, flavonoids, carotenoids, saponins, polyacetylenes, sterols, carbohydrates, vitamin C, mucilages and minerals, e.g., manganese (Grant et al., 1985). The physiological responses of Photosynthetic function is recognized as one of the most sensitive indicators of physiological processes to elevated temperatures changes in marigold flower the critical months are seriously issue in which the stomatal and non-stomatal gaseous exchanges under heat stress months (Paul et al., 2002). The heat stress was alter the stomata closure to reduce water loss, altering stomata and trichome density are the most common anatomical changes observed under high environmental temperatures in floriculture crops, the heat stress is a critical issue the high- 
temperature stress during summer months severely reduces the marketable quality and landscape survival capacity of marigold, the reduction in the flower diameter, and flower number in calendula has been reported with an increase in temperature (Warner \& Erwin, 2005). The results of our previously reported study also showed that morphological characteristics (plant height, leaf area, shoot and root weight, flower diameter, flower number and flower longevity) of calendula cultivars were reduced by high temperature stress, especially in prolonged exposure. However, the extent to which growth and flowering parameters were reduced differed among cultivars. High ambient temperatures causes heat stress and is a serious problem of the agricultural world (Hall, 2001). Temperature stress even high or low, are significant environmental factors that influence growth, development and physiological and biochemical structure of floriculture plants (IPCC, 2007). It speeds up the kinetic energy and movement of molecules in the membrane. The lipid bilayer produced more fluid either denaturing of protein, results an increased in the contents of fatty acid (Savchenko et al., 2002). Secondary metabolites play a role in tolerance during abiotic stress condition (Wahid, 2007). Stress protein, chemicals, and modification of hormonal are more prominent for supplemental application of nutrients (Mozafariyan, 2003; Liu et al., 2006; Feussner et al., 1997). Chemical fertilizers like Phosphate fertilizers put impact on growth of Calendula officinalis L (Mozafariyan, 2003) as quality and quantity of plants is effected by nutrients (Paul et al., 2002).

In stress condition presence of nitrogen plays a very crucial role to overcome the pressure of environment (Huang et al., 2004) in prevention of the photo oxidative damages (Kato et al. 2003; Waraich et al. 2011; Zhang et al., 2006). The nitrogen is considered as a muscularly mobile nutrient in a plant that moves with living cells, and its deficiency caused a problem in flowering and quality of plants (Marschner, 1995; Olson and Swallow, 1984). Phosphorous plays a dynamic part in minimizing heat stress and available to plants as an orthophosphate ions. It is a mobile nutrient in plant and transferred to sites of new growth and promotes the plant growing structures like (Cell division, cell elongation). Reduced crop yield observed under $\mathrm{N}$ deficiency, whereas supplements of $\mathrm{N}$ fertilizers can considerably upsurge productivity of the plants (Olson and Swallow, 1984; Grant et al., 1985 ; Olson and Swallow, 1984). The application of $\mathrm{N}$ fertilizers increased growth as it is primary constituent of proteins and are extremely liable to a loss in the range of 20 to $50 \%$ for dry matter production (Olson and Swallow, 1984 ; Grant et al., 1985). The electron flux such as $\mathrm{Li}$ and $\mathrm{K}$ play a vital role in abiotic stress condition, these fluxes have potential to attained a particular ion exchange capacity these ions should be bound to the heat radiation structure and help for heat tolerance mechanism in flowers and removed the heat in any part of plants (Grant et al., 1985).

The aims and objective of this article to explore active the role of induced modified mechanism of $\mathrm{N} \& \mathrm{P}$ application on quality, quantity and physiological responses under heat stress environment of marigold (Calendula officinalis $\mathrm{L}$ ) with advance monitoring and evaluation process. The non-reports are available on marigold nutritional requirements supplementary dozes with active nutritional responses under abiotic stress condition with trigger responses in metabolism changes under heat stress and its control through $\mathrm{N}$ and $\mathrm{P}$ fertilizers reported for the first time up to my best knowledge with modern and advances modelling and biocenology methods was performed in this study. The Systematic prompting the new physiological and morphological, biological responses of modified metabolic induction process of Calendula officinalis $L$ under heat stress periods couple with supplementary nutritional applications as safety of floriculture crops with efficient modelling of Potential nitrogen mineralization (PNM) of media were reported in the relevant section of this article and discussed with all necessary physiological responses under altered metabolism changes during stress periods with advanced biotechnology approaches and methods.

\section{Materials And Methods}

\section{Experimental site and location:}


The growing condition of Calendula officinalis L. were monitored in current investigation under stress at Horticultural Nursery, The University of Haripur, and Khyber Pakhtunkhwa, Pakistan. It is located 34.00 latitude and 72.93 longitudes and it is situated at elevation 537 meters above sea level.

\section{Seed sowing in pots with modern monitoring system}

The diameter of plastic container $200 \mathrm{~mm}$ deep was used, and the seed of Calendula officinalis $L$ was shifted into the pots with a mixture of different media shown in Table 1. The solarization of media was done for removal of any contamination before shifting into pots.

\section{Media Preparation with active materials}

The seeds were planted in a medium possess a cocopeat and sand (40:40 v/v) shown in Table 1. After 47 days of planting the seedling in four leaves stage were transplanted into large flower pots with the mixture of sand mould and cocopeat ratio of $(1: 1: 1)$.

\section{Treatments and Responses under stress periods}

The improvements of florets quality of marigold was planned to monitor under $\mathrm{N}$ and $\mathrm{P}$ dozes in heat stress conditions where different levels of $\mathrm{N}$ and $\mathrm{P}\left(\mathrm{N}_{2} 0.6 \& 0.8 \mathrm{~g}\right.$ and $\left.\mathrm{P}_{2} 0.9 \& 1 \mathrm{~g}\right)$ per pot were applied at four leaves stages of plant to evaluate the responses of these foliar sprays. The physiological responses of these fertilizers under the heat stress condition of Pakistan were implemented according to the growing periods of marigold.

\section{Vegetative and Reproductive growth of Marigold flowers under hot climatic condition}

Measurements of vegetative characters like plant height determined via a ruler at the end of the experiment by cutting above ground parts at the soil surface. Leaves, branches, petals numbers were also counted at the same time. Flower size and leaves length were calculated by a digital caliper (guanglu model) from complete flowers.

The weight of dry flower and leave was determined by following formula:

\section{Dry matter $(\%)=\underline{\text { Dry weight }}$}

\section{Fresh weight}

\section{Physiological Parameters of marigold under stress changes \\ Preparation of Malondialdehyde (MDA) and Calibration Standards}

The calibration curve for determination of concentration of MDA ( $1 \mathrm{mM})$ prepared in glacial acetic acid by dissolving the MDA $(31.35 \mathrm{mg})$ in $100 \mathrm{~mL}$ solvent followed by the preparation of different concentrations of $0.1,0.2,0.4,0.6$, and $0.8 \mathrm{mM}$ to prepare standard curve.

\section{Malondialdehyde (MDA) contents per gram FW (MDA)}

Two dissimilar extract prepared, using $100 \%$ pure acetic acid and mixed $50 \%$ acetic with $50 \%$ water. The $1 \mathrm{~mL}$ solution of TBA and $1 \mathrm{~mL}$ standard MDA was taken in a $10 \mathrm{~mL}$ test and mixed then heat on water bath at $95^{\circ} \mathrm{C}$ for 60 minutes followed by cooling at room temperature. The absorbance of the mixture recorded at $532 \mathrm{~nm}$ UV/Visible spectrophotometer, a blank sample of acetic acid or water was also run. The calibration curve prepared through standard solutions. The concentration of MDA calculated through from the calibration curve. 


\section{Chlorophyll contents}

Chlorophyll contents were measured in leaves $(100 \mathrm{mg})$ and crushed into motor piston in acetone ( $80 \%)$ followed by centrifugation about $2000 \mathrm{rpm}$ done for 3 mins. until colorless filtrate obtained. Absorbance of the filtrate recorded with blank $80 \%$ acetone on (UV-1800A) Shimadzu spectrophotometer. Pigment contents were determined by the method of Ahmed et al., 2018.

\section{Determination of $\mathrm{K}^{+}$contents of membrane}

The advanced technique Inductively coupled plasma (ICP) optical emission spectrometry used to measure the $\mathrm{K}^{+}$content in leaves which were dried in oven at $70^{\circ} \mathrm{C}$ for $48 \mathrm{~h}$ and then agitated in $5 \% \mathrm{H}_{2} \mathrm{SO}_{4}$ overnight followed by the determination of $\mathrm{K}^{+}$content using standard curves.

\section{Flux membrane stability of $\mathrm{Li}^{+}$and $\mathrm{K}^{+}$}

The Net fluxes of $\mathrm{Li}^{+}$and $\mathrm{K}^{+}$were measured in leaf samples using the NMT technique by moving microelectrodes and calculated by Fick's law of diffusion (Saadalla et al. 1990).

\section{Analysis of Phytochemical of marigold flower under heat stress periods}

\section{Total phenolic contents (TPC)}

Total phenolic contents (TPC) was measured using a Folin-Ciocalteu assay method where $1 \mathrm{~mL}$ of Folin-Ciocalteu reagent added into a diluted to 5 times in which $0.2 \mathrm{~mL}$ of sample and $0.8 \mathrm{~mL} 7.5 \% \mathrm{Na}_{2} \mathrm{CO}_{3}$ was added. The mixture were kept in dark for 20 mins then absorption was recorded at $765 \mathrm{~nm}$ against control sample (Stintzing et al. 2005). The gallic acid used to prepare the standard curve for determination of the concentration in mg equivalent of gallic acid (GAE) per gram.

\section{Determination of DPPH radicals scavenging activity}

Brand-Williams et al. (1995) method applied for the determination of DPPH radicals scavenging activity using with the $4 \mathrm{mg}$ DPPH dissolved in $100 \mathrm{~mL}$ of methanol and kept in dark place. The different concentrations were mixed with 5 $\mathrm{mL}$ of $0.004 \%$ DPPH solutions. The absorbance was measured at $517 \mathrm{~nm}$ after 20 minutes of reaction against the corresponding blank solution. The assay was performed in triplicates reactions.

Percentage inhibition of free radical DPPH was calculated based on control reading by following equation

\section{DPPH scavenged $(\%)=\quad\left(\underline{A}_{\text {con }}-\mathrm{A}_{\text {test }}\right) \times 100$}

$\mathrm{A}_{\text {con }}$

$A_{\text {con }}$ - is the absorbance of the control reaction

$A_{\text {test }}$ - is the absorbance in the presence of the sample of the extracts.

Responses of Nitrogen and phosphorus used efficiency methods in heat stress period 
The total nitrogen analyzed by the Kjeldahl method (Ladha et al., 2005) using $1 \mathrm{~g}$ leaves sample, digested with a mixture of $\mathrm{H}_{2} \mathrm{SO}_{4}-\mathrm{H}_{2} \mathrm{O}_{2}$. The phosphorus content was determined calorimetrically in digested samples with a solution of perchloric acid (72\%), ammonium molybdate (5\%, aminonaphtholsulphonic acid ( $0-2 \%), 0.5 \mathrm{~g}$ of sodium bisulphite and $6 \mathrm{~g}$ crystalline sodium sulphite. The total $\mathrm{N}$ and $\mathrm{P}$ contents determined through method given by (Dobermann, (2007). .

\section{Potential nitrogen mineralization (PNM) of media monitored and evaluation process}

The sample media was incubated under waterlogged at $30^{\circ} \mathrm{C}$ in a controlled temperature cabinet for 11 days (a 2: 1 water: media ratio was maintained during incubation). Three models, i.e. the single first-order kinetics model, the double first order kinetics model and the mixed first-order and zero-order kinetics model were used to simulate the cumulative mineralized $\mathrm{N}(\mathrm{NH} 4+-\mathrm{N}$ and TSN) in the laboratory and waterlogged incubation. The complete model of PNM shown in Table 5.

\section{Analysis of Growth media an nutritional profiling in growth and developmental stages}

The analysis of growth media comprises of total organic matter and total nitrogen of the soil. For total nitrogen of soil sample Kjeldahl method was used where $\mathrm{H}_{2} \mathrm{SO}_{4}$ used for titration. Organic matter estimated by dissolving $1 \mathrm{~g}$ air-dried soil sample in $10 \mathrm{ml} 1 \mathrm{~N}$ potassium dichromate solution and $20 \mathrm{ml}$ concentrated sulfuric acid in a $500 \mathrm{ml}$ beaker, using a dispenser to mix the suspension for 30 minutes, then $200 \mathrm{~mL}$ of distilled water and ` $10 \mathrm{ml}$ concentrated orthophosphoric acid added followed to cool it. and mixture was allowed to cool. Titration of the mixture carried out by ammonium sulfate solution using diphenylamine

\section{Responses of Respirational changes under heat stress condition}

The respirational rate was determined using a portable infrared gas analyzer 6250, LI-COR, Inc., Lincoln, Nebr.), connected with automatic software to record the reading during critical months.

\section{Statistical Analysis}

A complete randomized block design pot experiment conducted with various concentrations of $\mathrm{N}$ and $\mathrm{P}$ followed by the monitoring of their interaction under stress condition with the plants by analysis of variance (ANOVA). The posthoc test with student newman Kuehl's (SNK) multiple-range test $\left({ }^{*} p<0.05\right)$ were calculated. All samples were normal, and homogeneous variances were tested using the Levene and Cochran tests were implemented on SPSS 21.0 Inc., Chicago, USA software. The mineralization process was measured from the cumulative amounts of $\mathrm{NH}_{4}{ }^{+}-\mathrm{N}_{\text {with non- }}$ liner regression procedure.

\section{Results And Dissuasion}

\section{Morphological and metabolism responses under growth and developmental changes by N \&P doses}

It was observed that the growth of marigold plant showed modification under $\mathrm{N}$ and $\mathrm{P}$ application where substantial variations reported in height and number of leaves of plant in comparison with control plant (Table 2) under applied $0.9 \mathrm{~g}$ dose of $\mathrm{N}_{2}$ (8.60 cm and 15.44 respectively) while plant cultivated with phosphorus plant reflect height of 14.22 $\mathrm{cm}$ over control. Variations in fresh weight of plants were observed among the fertilizer applications, and the differences were statistically significant as shown in Table1. Fresh weight $(72.24 \mathrm{~g})$, leaf length $(9.86 \mathrm{~cm})$, numbers of flowers (5.88), and the number of branches (8.1) were increased significantly by nitrogen application over control. The plants which were applied with nitrogen $(0.9 \mathrm{~g})$, and phosphorus $(1 \mathrm{~g})$ showed maximum values $(6.15 \mathrm{~cm})$ and $(5.09$ 
$\mathrm{cm}$ ) respectively as compared to control (Fig. 1). Vegetative characters like growth and plant height increases under nitrogen application as reported by Bielskiand and Beata Szwejkowska (2012). N is biologically supplier of H, C, O and S elements as these are primary contents used in the synthesis of the amino acid and protein contents in growing part of flowering plants (Ladha et al. 2005 ; Cassman et al. (2002 ; Husaain et al. (2011); Szwejkowska and Stanisław Bielski, 2012). N improves the quality and quantity attributed to the flowering plants due to continuously increase the cell assimilates and involve in more cell division consequently increase number of leaves of flowering plants (Abdul Kareem et al. (2014). Pandey and Mishra, (2005) discloses that the application of N and P improves the vegetative and reproductive parts of flowers. Literature search showed that marigold flower showed improved growth under $\mathrm{N}$ application Hazarika et al. (2000). The current investigation is in accordance with the findings of Beata Kraol (2011)

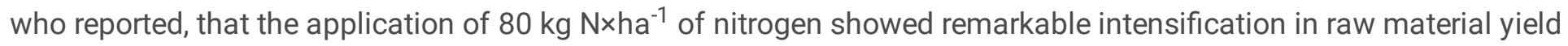
of the plant while the yield of flower heads did not vary noticeably for same dose of fertilizers Hussein et al. (2011) demonstrated that significant difference in the flower diameter between the treated and controls treatments of marigold with doses of $\mathrm{N} 1.5$ and $3.0 \mathrm{~g}$ per pot.

\section{Evaluation and monitoring of physiological changes under the application of N\& $\mathrm{P}$ at heat stress months}

The physiological parameters showed significant differences between treatments during the study of 2015-16 in three different heat stress periods like (May, June, and July) (at $P>0.05$ ) shown in table 3 . In the month of May the maximum contents of Malondialdehyde (MDA) under the application of $1 \mathrm{~g}$ of $\mathrm{P}$ in comparison of control (120 per $\mathrm{g}$ FW). Higher contents of Chrophylls were noted in $\mathrm{N}$ application followed by $\mathrm{P}$ and lower contents of Chrophylls were measured in control. A similar trend of Lipid Peroxidation Assay per gram FW and Li and K contents Flux membrane stability $\left(\mathrm{mg} \mathrm{dm}^{-3}\right)$ were measured by application of $1 \mathrm{~g}$ of P. However in this month lower contents were noted in control. Higher values of Malondialdehyde (MDA) 155 per $\mathrm{g}$ FW recorded in the month of June by the application of 1 $\mathrm{g}$ of $\mathrm{P}$ in comparison to control. Similar trends were showed by the use of $\mathrm{N}_{2} 0.9 \mathrm{~g}$ of Chrophyll contents in leaves of marigold. Lipid Peroxidation Assay per gram FW was higher in June month by application of $1 \mathrm{~g}$ of $\mathrm{P}$. The net higher contents of Malondialdehyde (MDA) under $1 \mathrm{~g}$ of $\mathrm{P}$ in the month of July was observed in comparision of Malondialdehyde (MDA) contents noted in control. Similarly, higher contents of Chrophylls were measured in both months of June and July. Slight variations in Lipid Peroxidation Assay per gram FW and Li and K content Flux membrane stability $\left(\mathrm{mg} \mathrm{dm}^{-3}\right)$ were observed in the month of July. Several herberous and succulents' plants are severely damaged by heat stress. The results indicated in Table 3 maximum contents of Malondialdehyde (MDA), as to the signal responses of root to shoot of marigold (Mehmet et al., 2009). This signal mechanism improves by the application of supplementary nutrient supply to the flowering plants Rahbarian et al. (2010).

Heat stress in months of June and July is a serious problem in floriculture industry throughout the world (Fini et al. (2011). In months of July high Lipid Peroxidation Assay per gram FW and Li and K contents Flux membrane stability $\left(\mathrm{mg} \mathrm{dm}^{-3}\right)$ due to the response of heat stress in different parts of marigold were observed. These fluxes are stable in the membrane (Yin et al., 2008). The study revealed that the physiological responses under heat stress condition are related to the quality of marigold by the application of nutrients in stress months. $\mathrm{N}$ and $\mathrm{P}$ involve in reverting the process in plants through continuous adding in different parts of flowering to save the organs and injured parts of flowering plants (Király and Czövek, 2002). The study showed the linked with respiration and physiological response for production of dry matter indispensable to evaluate the significant increase of $\mathrm{N}$ uptake for better flowers quality and yield (Yin et al., 2008).

Marigold plants faced problem of lower flowers production and poor quality under heat stress conditions due to its internal structural changes and cellular components. The reactive oxygen species (ROS) caused the internal membrane damages and losses of membrane stability during heat stress conditions (Jain et al., 2001). The high level 
of lipid peroxidation related to the MDA content, against heat response observed in marigold organs, clearly indicated that the oxidative stress generated under the effects of a high heat stress period. Several crops (Maize, wheat cotton) under heat stress showed an increased the contents of MDA (Jain et al., 2001; Király and Czövek, 2002; Sofo et al., 2004; Yin et al., 2008).

Chlorophyll is a green pigment and obligates part in photosynthesis activity of plants and considered as a food supply component of flowering plants (Jain et al., 2001; Gupta et al., 2017). Heat stress period is a critical part for photosynthetic pigments. The structures may damage and reverse food in stored parts of organs are lost. The $\mathrm{N}$ and $\mathrm{P}$ nutrients play a vital role to minimise these oxidative damages Falk et al. (1999). The application of these additional nutrients through fertilizers improved the carbon exchange activities in flowering plants and enhanced the pigments of chlorophyll in all parts of plants (Sofo et al., 2004).

\section{Application of N\& P on Phytochemicals changes of Pot marigold responses with advance biological changes}

The higher contents of total phenolic compound ( $84.41 \mathrm{mg} \mathrm{GAE} / \mathrm{g})$, total carotenoids $(16.2 \mathrm{mg} / 100 \mathrm{~g})$, and Total flavonoids content $(0.90 \mathrm{mg} / 100 \mathrm{~g})$ and total antioxidants $(36.3 \% \mathrm{DPPH})$ were noted in $\mathrm{N}_{2} 0.9 \mathrm{~g}$ application over control $(P>0.05)$ shown in table 4. Phytochemical play a vital role in oxidative stress (Jain et al. 2001). The higher content of Phenyl ammonia lyase and decreased peroxidase activity by the application of nutrient in oxidative stress periods was similar to report of Rivero et al.,(2001). The phytochemicals are produced in roots and translocate into the other parts of flowering plants. The current study showed that the enhance contents of these phytochemicals produce in root after application of these nutrients ions, and transferred into leaves, nodes, internodes, buds and final involves in covering the injured organ couple with removal of heat stress injuries in plants (Jain et al. 2001). Application of $\mathrm{N}$ and $\mathrm{P}$ play a role in oxidative stress and a significant role in heat stress months in the flowering plants which develop the ability to tolerate heat stress condition (Falk et al. 1999).

\section{Net changes of Dry weight of flower and leaves responses of marigold}

The dry weight of flowers and leaves were presented in Fig 3. The higher number of Flowers noted under $1 \mathrm{~g}$ of $\mathrm{P}$ application over control. The higher number of dry leaves was observed in $1 \mathrm{~g}$ of $\mathrm{P}$ application. The fact is evident that the higher rate of phosphate fertilizer showed maximum contents of florets parts and leaf materials (Jain et al., 2001; Gupta et al., 2017). Sofo et al., (2004) also report that the dry weights were increased due to extra supply of nutrients.

\section{Adavnce modeling of net rate of $\mathrm{N}$ and $\mathrm{P}$ Efficiency up take induction process of marigold:}

The net efficiency rate of $\mathrm{N}$ and $\mathrm{P}$ of marigold shown in Fig 4. The net rate of $\mathrm{N}$ and $\mathrm{P}$ efficiency was increased due to a higher supply of nutrients of both doses of $\mathrm{N}$ and $\mathrm{P}$. The higher content of both rates were measured by the application of $\left(\mathrm{N}_{2} 0.9 \mathrm{~g}\right.$ and $\left.\mathrm{P}_{2} 1 \mathrm{~g}\right)$. While in Fig 5 showed that $\mathrm{N}$ rate of efficiency was lower before application of $\mathrm{N}$ supply as compared to after application to marigold. The higher contents of Net $\mathrm{N}$ rate efficiency were recorded in 0.9 $\mathrm{g}$ of $\mathrm{N}_{2}$ followed by $1 \mathrm{~g}$ of $\mathrm{P}$ over control, and minor increased is reported after application. The similar trend in Phosphate fertilizer reported in earlier reported work (Dobermann, 2007). The nutrient supply increased the NUE and PUE after application of $\mathrm{N}$ and $\mathrm{P}$ (Cassman et al., 2002; Dobermann, 2007). The amount of $\mathrm{N}$ increased after estimation 5 to $20 \%$ in different crops (Howarth et al., 2002) and 52\% (Janzen et al., 2003). Application of N improves the NUE in cereals crops Dobermann, 2007).

\section{Plant responses of Net rate of NUE and PUE under Heat Stress Periods its supply and changes}

The net rate of NUE and PUE under heat stress conditions represented in Fig $5,6,7$. It was found that the high doses of both $\mathrm{N}$ and $\mathrm{P}$ were effective on metabolism of the plant in the Month of May which was (1.4\%) under $0.9 \mathrm{~g}$ of $\mathrm{N}_{2}$ 
followed by the (14.5\%) in the month of June. While PUE was $32 \%$ under $1 \mathrm{~g}$ of P application. The month of July, the most critical period of heat stress where the assembles rate of $\mathrm{N}$ efficacy rate was (1.7\%), over Phosphate application which showed a maximum rate increased (34\%) over control for both $\mathrm{N}$ and $\mathrm{P}$ net rate efficiency.

The summer season is critical for plants growth due to high temperature. The additional application of these nutrients plays a role in minimizing heat stress in these months as reported by Ladha et al. (2005) Cassman et al. (2002), Ladha et al. (2005), Syers et al., 2008).. The results were shown in Fig 6. The liner changes of $\mathrm{N}$ net rate efficiency showed a value of $r^{2}=0.9641$ in both months of (May and June) while in July the net $N$ rate efficacy value was 0.592 . The Net $P$ rate efficiency showed 0.6413 in the month of May, however in June 0.8232 and July was 0.8333 . The liner changes showed that maximum variations were recorded in these months.

The Nitrogenous and Phosphates fertilizers had potential role in heat stress periods (Hasanuzzaman et al. 2013). Syers et al., (2008) reported that the heat stress suddenly damages the root system and affect the tissues of xylem and phloem of flowering plants while application of fertilizer neutralizes the heat stress due to a network of ions which covered the effected parts of plants (Ladha et al. 2005 ; Cassman et al. 2002). The injured cell showed a deprived function during the stress periods. The timely application of nutrients makes their role positive in stress periods (Liu et al., 20110. Literature search revealed that the crops condition under heat stress while but minute work is reported on the flowering crops (Ladha et al. 2005 ; Cassman et al. 2002 ;. Dobermann, 2007 ;; Rehman, 2016 ;. Lima et al. 2015 ).

\section{Cumulative respirational changes and changes process of marigold flower under heat stress conditions}

Several trials on respirational changes were recorded under heat stress conditions (Ladha et al. (2005) Cassman et al. (2002) Dobermann (2007), Rehman, (2016). Lima et al. (2015). Statistical analysis regarding the physiological parameters showed significant differences at $P>0.05$ for treatments during the year 2015-16 shown in fig 2 . The results showed that the maximum respirational rates were recorded in control while lower values were obtained in $\mathrm{N}_{2}$ $0.6 \mathrm{~g}$ which was slow at next dose than the increase in turn at $\mathrm{P}$ application. These results are according to the findings of Hussein et al. (2011) who reported significant role of respiration on growth and yield of marigold under $\mathrm{N}$ and $\mathrm{P}$ application. The improvement in the photosynthetic pigments compounds which enhanced the production of dry matter, seems to be a valuable tool to interpret the relationship between photosynthesis, respiration, and dry matter production, and, therefore, quality and its yield improves (Hussein et al. (2011. Growth efficiency may be associated with the morphology of plants as well as with the chemical nature of respiration which is governed by the environmental conditions and genetic modification and heat tolerance system (Jain et al., 2001).

\section{New Potential nitrogen mineralization (PNM) model of media and Organic residues of media responses under heat stress changes in marigold}

The results indicated that the zero-order kinetics model were used to simulate the cumulative mineralized formed of $\mathrm{N}$ $(\mathrm{NH} 4+-\mathrm{N}$ and TSN) in the laboratory and waterlogged incubation was measured in marigold. The complete model of PNM shown in Table 5. The higher value of $\mathrm{NH}^{4}{ }_{+} \mathrm{N}\left(\mathrm{mg} \mathrm{kg}^{-1}\right) 190$ was found in $1 \mathrm{~g}$ of $\mathrm{P}$ application, $\mathrm{NH}_{3+} \mathrm{N}_{\left(\mathrm{mg} \mathrm{Kg}^{-1}\right)}$ 2.22 was found in same doze of $\mathrm{P}$ application. The net uptake of $\mathrm{N} \mathrm{kg.g} \mathrm{g}^{-1} 4.20$ was reordered in application of $0.9 \mathrm{~N}$ similar in organic matters and $\mathrm{C}: \mathrm{N}$ were found here in application of $1 \mathrm{~g} \mathrm{p}$ and higher doses of $\mathrm{N}$. The higher value of $\mathrm{N}$ org (media) and $\mathrm{N}$ org (media) + min 4.1 and 5.5 was measured in application of $\mathrm{N} 0.9 \mathrm{~g}$ per pot shown in table 6 . The lower values of $\mathrm{N}$ in org and media response were lower due to addition nitrogen was less in media and residue based changes were found as reported by Araus in his experiment. The mineral response in media was changed to less update of $\mathrm{N}$ while this critical periods were the $\mathrm{N}$ its update is major response of growth in flowers Lima et al. 2015, Rehman, 2016.). 


\section{Conclusion}

Exposure the plant parts for prolonged heat stress periods has negative effects on phytochemical, physiological process of calendula under critical months of summer in Asia regions. The study was prove the application of Nitrogen and Phosphorus fertilizers play an effective role in minimising the damages during summer seasons periods as supplementary dozes apply on their active growth and developmental stages. The new and advanced biotechnology systematic changes were held in this study as new science of era for safely of florets. The application of Nitrogen $1 \mathrm{~g}$ showed a potential improvement of Systematic prompting the new physiological and morphological, biological responses with a positive aspect on phytochemical and physiological improvement by Phosphorus apply at $1 \mathrm{~g}$. The foliar sprays of $\mathrm{N}$ and $\mathrm{P}$ has potential effects on physiological changes and tagger the response of growth and developmental process at active periods by the timely application of nutritional dozes at stress periods and proved the NUE and PUE was best method for plant health response's The efficacy of Nitrogen and Phosphorus is clear indicator of plants observed nutrients at critical response.

\section{Declarations}

\section{Ethics declarations}

Ethics approval and consent to participate

\section{Not applicable.}

\section{Consent for publication}

Not applicable.

\section{Competing interests}

The other authors declare that they have no competing interests.

Acknowledgements: The authors are highly appreciated the Department of Horticulture The University of Haripur, Pakistan and with coordination of Department of the Chemistry University of Karachi, Pakistan to complete this project.

\section{Authors' Contributions}

WA contributed in collecting plant sample, identification and herbarium confection. Conceived and designer the experiments: WA, RA. Performed the experiments RA, AQ,AM, ML. Analyzed the data: WA,AQ,MA,AM,SMK. Wrote the paper: WA, RA, ML, and SMK. All the authors have read the final manuscript and approved the submission.

\section{Compliance with ethical standards}

No potential conflict of interest was reported by the authors.

\section{References}

Ahmed, W. et al. Extraction of diverse polyphenols in relation with storage periods of Citrus paradisi CV. Shamber through HPLC-DAD technique using different solvent. J. of Food Sci. and Tech. 56(1):384-390 (2019). 
Ahmed, W. et al. Pharmacological studies of Adhatoda vasica and Calotropis procera as resource of bio-active compounds for various diseases. Pak. J. Pharm. Sci. 31(5):1975-1983 (2018).

Araus, W. et al. Chlorophyll fluorescence as a selection criterion for grain yield in durum wheat under Mediterranean conditions. Field Crops Res. 55:209-223 (1998).

Beata, I., The Effect of Different Nitrogen Fertilization Rates on Yield and Quality of Marigold (Calendula Officinalis L.'Tokaj') Raw Material. Acta Agrobotanica 64:29-34 (2011).

Falk, $\mathrm{N}$ et al. Spatial distribution and life-cycle timing of zooplankton in the marginal ice zone of the Barents Sea during the summer melt season. J. Plankton Res. 21:1241-264 (1999).

Falk, S. et al. In Advances in Photosynthesis, V.5, Photosynthesis and the Environment. Kluwer Academic Publishers, Dordrecht Boston London. pp. 367-385. (1996)

Ganjali, H. et al. Effects of Sowing Date, Plant Density and Nitrogen Fertilizer on Yield, Yield Components and Various Traits of Calendula officinal American-Eurasian J. Agri. and Environment Sci. 9:149-155 (2017).

Grant, $\mathrm{C}$ et al. The effect of fall-applied $\mathrm{N}$ and $\mathrm{P}$ fertilizers and timing of $\mathrm{N}$ application on yield and protein content of winter wheat grown on zero-tilled land in Manitoba. Canadian Journal of Soil Science. 65:621-628 (2011).

Hussein, $\mathrm{M}$ et al. Effect of some fertilizers on botanical and chemical characteristics of pot marigold plant (Calendula officinalis L.) J. of Horticulture Sci and Ornamental Plants. 3:220-231 (2011).

Jain, MG., Marthur, S. Koul, Sarin, NB. 2001. Ameliorating effects of proline on salt stress induced lipid peroxidation in cell lines of groundnut (Arachis hypogea L.). Plant Cell Respiration. 20:463-468.

Jevdovic, J. The Effects of Location and the Application of Different Mineral Fertilizers on Seed Yield and Quality of Pot Marigold (Calendula officinalis L.). Turkish J. of Field Crops. 18:1-7 (2011).

Kiraly, I et al. Changes of MDA level and $\mathrm{O}_{2}$ scavenging enzyme activities in wheat varieties as a result of PEG treatment. Acta Biologica Szegediensis.46: 3105-106 (2002).

Kumar, A., Singh, Ak. 2011. Effect of spacing and nitrogen levels on vegetative growth flowering behavior and yield of calendula (Calendula officinalis L.). Plant Archives. 11:941-944.

Mehmet, Y. et al. 2009. Membrane thermal stability at different developmental stages of spring wheat genotypes and their dialed cross population starim bilimleri dergisi. 15:293-300 (2009).

Mohammad, S. Light Absorption and Carotenoid Synthesis of Pot Marigold (Calendula officinalis L.) in Response to Phosphorous and Potassium Varying Levels. Not Sci. Bio. 3:46-50 (2011).

Navid, N. et al. The effect of fall applied $\mathrm{N}$ and $\mathrm{P}$ fertilizer and timing of $\mathrm{N}$ application on yield and protein content of winter wheat grown on zero-tilled land in Manitoba. Canadian J. Soil Sci. 65:621-628 (2011).

Olson, R. et al. Fate of labeled nitrogen fertilizer applied to winter wheat for five years. Soil Sci. Society American J.. 48:583-586 (2011).

Pala, J. et al. Seasonal Variation in chemical constituents of Santolina rosmarinifolia L. SSP. Rosmarinifolia. Biochem. Sys and Ecology. 29:663-672 (2012).

Page $11 / 18$ 
Sofo, A., Dichio, B. Xiloyannis, Masia, C. 2004. Effects of different irradiance levels on some antioxidant enzymes and on malondialdehyde content during dewatering in olive tree. Plant Science. 166:293-302.

Vijay, N. Influence of Nitrogen, Phosphorus and Potassium Fertilizer on Biochemical Contents of Asparagus recomposes (Wild) Root Tubers. Res J. of Environmental Sci. 3:285-291 (2009).

Yin et al. Effects of short-term heat stress on oxidative damage and responses of antioxidant system in Lilium longifl orum.Plant Growth Regulation. 54:45-54 (2008).

\section{Tables}

Table 1 :Physicochemical properties and active ingredient of media used for seeds and roots culture of marigold flower

\begin{tabular}{|lll|}
\hline Properties & Media (Cocopeat + Sand) for seeds) & Media (Cocopeat+ Sand+ Mould) for root \\
\hline $\mathrm{pH}$ & 7.02 & 6.90 \\
\hline Available P (mg/Kg) & 25.0 & 59.0 \\
\hline Total N (\%) & 2.8 & 5.3 \\
\hline Organic Carbon (\%) & 2.0 & 8.0 \\
\hline
\end{tabular}

Table 2: Mean comparison of the effect of different level of $\mathrm{N}$ and $\mathrm{P}$ on Plant height, Total number of leaves, fresh weight, leaf length, number of branches, and number of flowers of marigold

\begin{tabular}{|c|c|c|c|c|c|c|}
\hline Fertilizers & $\begin{array}{l}\text { Plant height } \\
\text { (cm) }\end{array}$ & $\begin{array}{l}\text { Total number of } \\
\text { leaves }\end{array}$ & $\begin{array}{l}\text { Fresh } \\
\text { weight (g) }\end{array}$ & $\begin{array}{l}\text { Leaf length } \\
\text { (cm) }\end{array}$ & $\begin{array}{l}\text { Number of } \\
\text { branches }\end{array}$ & $\begin{array}{l}\text { Number of } \\
\text { flowers }\end{array}$ \\
\hline & $4.95 d$ & $10.55 \mathrm{e}$ & $18.45 \mathrm{e}$ & $5.4 d$ & $3.66 \mathrm{e}$ & $3.22 \mathrm{~d}$ \\
\hline \multicolumn{7}{|l|}{ Control } \\
\hline $\begin{array}{l}\text { N } 0.6 \mathrm{~g} \text { per } \\
\text { pot }\end{array}$ & $8.47 b$ & $14.44 b$ & $70.24 b$ & $7.86 \mathrm{~b}$ & $7.1 b$ & $4.88 c$ \\
\hline $\begin{array}{l}\mathrm{N} 0.9 \mathrm{~g} \\
\text { per pot }\end{array}$ & $8.60 \mathrm{a}$ & $15.44 a$ & $72.24 \mathrm{a}$ & $9.86 a$ & $8.1 \mathrm{a}$ & $5.22 b$ \\
\hline $\begin{array}{l}\text { P } 0.8 \mathrm{~g} \mathrm{per} \\
\text { pot }\end{array}$ & 7.17c & $13.22 d$ & $59.81 d$ & $7.2 \mathrm{cb}$ & $4.66 c$ & $4.66 c$ \\
\hline $\begin{array}{l}\text { P } 1 \mathrm{~g} \text { per } \\
\text { pot }\end{array}$ & $7.70 \mathrm{cb}$ & $14.22 \mathrm{c}$ & $60.82 c$ & $7.1 \mathrm{bc}$ & $3.22 \mathrm{~d}$ & $5.88 a$ \\
\hline $\begin{array}{l}\text { LSD = } \\
0.012\end{array}$ & & & & & & \\
\hline
\end{tabular}

Note: Different letters in superscript within the same row indicate significant difference among different harvesting dates at $p<0.05$ by LSD test. 0.011 
Table 3: Mean efficacy of various levels of N and P on Malondialdehyde (MDA) contents, Chrophyll contents, Lipid Peroxidation Assay in leaves, $\mathrm{Li}$ and $\mathrm{K}$ contents of pot marigold during stress months

\begin{tabular}{|c|c|c|c|c|c|}
\hline $\begin{array}{l}\text { Months } \\
\text { of } \\
\text { Heat } \\
\text { stress }\end{array}$ & Treatments & $\begin{array}{l}\text { Malondialdehyde } \\
\text { (MDA) contents per } \\
\text { gram FW }\end{array}$ & $\begin{array}{l}\text { Chrophyll } \\
\text { contents in } \\
\text { leaves (\%) }\end{array}$ & $\begin{array}{l}\text { Lipid } \\
\text { Peroxidation } \\
\text { Assay per gram } \\
\text { FW }\end{array}$ & $\begin{array}{l}\mathrm{Li} \text { and } \mathrm{K} \text { contents Flux } \\
\text { membrane stability (mg } \\
\mathrm{dm}-3 \text { ) }\end{array}$ \\
\hline \multirow[t]{5}{*}{ May } & Control & $120 \mathrm{e}$ & $20 e$ & $14 b$ & $30 \mathrm{e}$ \\
\hline & $\begin{array}{l}\text { N } 0.6 \mathrm{~g} \text { per } \\
\text { pot }\end{array}$ & $125 d$ & $40 \mathrm{~b}$ & $8 e$ & $50 d$ \\
\hline & $\begin{array}{l}\mathrm{N} 0.9 \mathrm{~g} \text { per } \\
\text { pot }\end{array}$ & $130 c$ & $42 a$ & $9 d$ & $55 c$ \\
\hline & $\begin{array}{l}\mathrm{P} 0.8 \mathrm{~g} \text { per } \\
\text { pot }\end{array}$ & $140 \mathrm{~b}$ & $35 d$ & $12 c$ & $60 b$ \\
\hline & $\begin{array}{l}\text { P } 1 \mathrm{~g} \text { per } \\
\text { pot }\end{array}$ & $150 a$ & $38 c$ & $15 a$ & $65 a$ \\
\hline \multirow[t]{5}{*}{ June } & Control & 110ef & $18 \mathrm{e}$ & $13 b$ & $25 f$ \\
\hline & $\begin{array}{l}\text { N } 0.6 \mathrm{~g} \text { per } \\
\text { pot }\end{array}$ & $130 d$ & $39 b$ & $7 e$ & $60 \mathrm{de}$ \\
\hline & $\begin{array}{l}\text { N } 0.9 \mathrm{~g} \text { per } \\
\text { pot }\end{array}$ & $135 c$ & $41 a$ & $10 d$ & $70 a$ \\
\hline & $\begin{array}{l}\text { P } 0.8 \mathrm{~g} \mathrm{per} \\
\text { pot }\end{array}$ & $141 b$ & $34 d$ & $11 \mathrm{c}$ & $64 \mathrm{~cd}$ \\
\hline & $\begin{array}{l}\text { P } 1 \mathrm{~g} \mathrm{per} \\
\text { pot }\end{array}$ & $155 a$ & $37 c$ & $16 a$ & $68 b$ \\
\hline \multirow[t]{6}{*}{ July } & Control & $105 f$ & $18 \mathrm{e}$ & $10 \mathrm{e}$ & $24 \mathrm{ef}$ \\
\hline & $\begin{array}{l}\text { N } 0.6 \text { g per } \\
\text { pot }\end{array}$ & $140 e$ & $39 b$ & $12 d$ & $50 d$ \\
\hline & $\begin{array}{l}\mathrm{N} 0.9 \mathrm{~g} \text { per } \\
\text { pot }\end{array}$ & $149 \mathrm{~cd}$ & $41 a$ & $18 a$ & $72 a$ \\
\hline & $\begin{array}{l}\text { P } 0.8 \mathrm{~g} \text { per } \\
\text { pot }\end{array}$ & $155 b$ & $34 d$ & $14 \mathrm{c}$ & $60 c$ \\
\hline & $\begin{array}{l}\text { P } 1 \mathrm{~g} \text { per } \\
\text { pot }\end{array}$ & $158 a$ & $37 c$ & $17 b$ & $69 b$ \\
\hline & $\begin{array}{l}\text { LSD = } \\
0.011\end{array}$ & & & & \\
\hline
\end{tabular}

Note: Different letters in superscript within the same row indicate significant difference among different harvesting dates at $p<0.05$ by LSD test.

Table 4: Means comparison of various levels of $\mathrm{N}$ and $\mathrm{P}$ on Phytochemicals Changes of Marigold flowers 


\begin{tabular}{|c|c|c|c|c|c|c|c|c|}
\hline \multirow{3}{*}{$\begin{array}{l}\text { Years } \\
\text { Treatments }\end{array}$} & \multicolumn{4}{|l|}{2015} & \multicolumn{4}{|l|}{2016} \\
\hline & \multicolumn{8}{|c|}{ Phytochemicals of marigold with two growing years } \\
\hline & $\begin{array}{l}\text { TPC } \\
\text { (mg } \\
\mathrm{GAE} / \mathrm{g}\end{array}$ & $\begin{array}{l}\text { TA } \\
\text { (\%DPPH) }\end{array}$ & $\begin{array}{l}\mathrm{TC} \\
(\mathrm{mg} / 100 \mathrm{~g})\end{array}$ & $\begin{array}{l}\text { TFC } \\
(\mathrm{mg} / 100 \mathrm{~g})\end{array}$ & $\begin{array}{l}\text { TPC } \\
\text { (mg } \\
\text { GAE/g }\end{array}$ & $\begin{array}{l}\text { TA } \\
\text { (\%DPPH) }\end{array}$ & $\begin{array}{l}\mathrm{TC} \\
(\mathrm{mg} / 100 \mathrm{~g})\end{array}$ & $\begin{array}{l}\text { TFC } \\
(\mathrm{mg} / 100 \mathrm{~g})\end{array}$ \\
\hline Control & $\begin{array}{l}50.32 \\
e^{-12}\end{array}$ & $30.3 \mathrm{e}$ & $12.1 \mathrm{e}$ & $0.51 \mathrm{e}$ & $e^{49.32}$ & $30.3 \mathrm{e}$ & $11.1 \mathrm{e}$ & $0.51 \mathrm{e}$ \\
\hline $\begin{array}{l}\text { N } 0.6 \mathrm{~g} \text { per } \\
\text { pot }\end{array}$ & $65.55 d$ & $34.31 b$ & $13.3 \mathrm{~d}$ & $0.71 \mathrm{c}$ & $65.55 d$ & $34.31 \mathrm{~b}$ & $13.3 \mathrm{~d}$ & $0.71 \mathrm{c}$ \\
\hline $\begin{array}{l}\mathrm{N} 0.9 \mathrm{~g} \text { per } \\
\text { pot }\end{array}$ & $\begin{array}{l}84.41 \\
\mathrm{a}\end{array}$ & $36.3 \mathrm{c} \mathrm{a}$ & $16.2 \mathrm{a}$ & $0.90 a$ & $\begin{array}{l}84.41 \\
\mathrm{a}\end{array}$ & $36.3 \mathrm{c} \mathrm{a}$ & $16.2 \mathrm{a}$ & $0.90 a$ \\
\hline $\begin{array}{l}\text { P } 0.8 \mathrm{~g} \text { per } \\
\text { pot }\end{array}$ & $\begin{array}{l}71.22 \\
c\end{array}$ & $33.1 \mathrm{c}$ & $15.2 \mathrm{~b}$ & $0.81 \mathrm{~b}$ & $\begin{array}{l}71.22 \\
c\end{array}$ & $32.1 \mathrm{c}$ & $15.2 \mathrm{~b}$ & $0.81 \mathrm{~b}$ \\
\hline $\begin{array}{l}\text { P } 1 \mathrm{~g} \mathrm{per} \\
\text { pot }\end{array}$ & $\begin{array}{l}83.21 \\
b\end{array}$ & $32.2 d$ & $14.1 \mathrm{c}$ & $0.70 \mathrm{~d}$ & $\begin{array}{l}82.21 \\
b\end{array}$ & $31.2 d$ & $13.1 \mathrm{c}$ & $0.70 \mathrm{~d}$ \\
\hline LSD $=0.01$ & & & & & & & & \\
\hline
\end{tabular}

Table 5 : advanced modern model of Organic residues of media responses

\begin{tabular}{|llllll|}
\hline Treatments & $\mathrm{NH}_{4+} \mathrm{N}\left(\mathrm{mg} \mathrm{kg}^{-1}\right)$ & $\mathrm{NH}_{3}+\mathrm{N}\left(\mathrm{mg} \mathrm{Kg}^{-1}\right)$ & $\mathrm{N} \mathrm{kg}^{-1}$ & Organic matter g & $\mathrm{C}: \mathrm{N}$ \\
\hline Control & 70 & 0.40 & 2.0 & 220 & 10.2 \\
\hline N 0.6 g per pot & 110 & 1.1 & 4.0 & 270 & 11.1 \\
\hline N 0.9 g per pot & 170 & 1.25 & 4.20 & 310 & 12.4 \\
\hline P 0.8 g per pot & 180 & 2.1 & 2.20 & 320 & 20.2 \\
\hline P 1 g per pot & 190 & 2.22 & 2.21 & 330 & 22.2 \\
\hline & & & & \\
\hline
\end{tabular}

Table 6 New and active Potential nitrogen mineralization (PNM) of media calculations methods

\begin{tabular}{|lll|}
\hline Treatments & N org (media) & N org (media) + min \\
\hline Control & $2.1 \mathrm{~d}$ & $1.1 \mathrm{e}$ \\
\hline N 0.6 g per pot & $2.2 \mathrm{c}$ & $2.6 \mathrm{~d}$ \\
\hline N 0.9 g per pot & $4.1 \mathrm{a}$ & $5.5 \mathrm{a}$ \\
\hline P 0.8 g per pot & $2.2 \mathrm{c}$ & $3.3 \mathrm{c}$ \\
\hline P 1 g per pot & 2.6b & $4.1 \mathrm{~b}$ \\
\hline
\end{tabular}


Different letters in superscript within the same row indicate significant difference among different harvesting dates at $\mathrm{p}<0.05$ by LSD test.

\section{Figures}
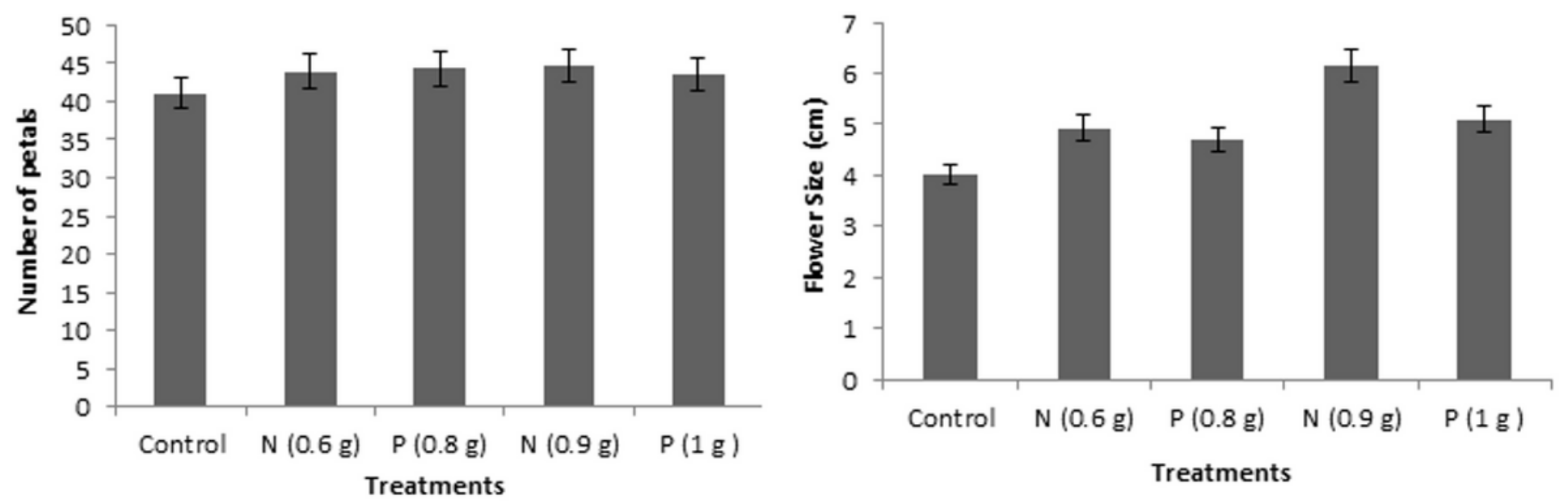

Figure 1

Effects of Nitrogen and Phosphorus foliar application on number of petals and Flower size of marigold

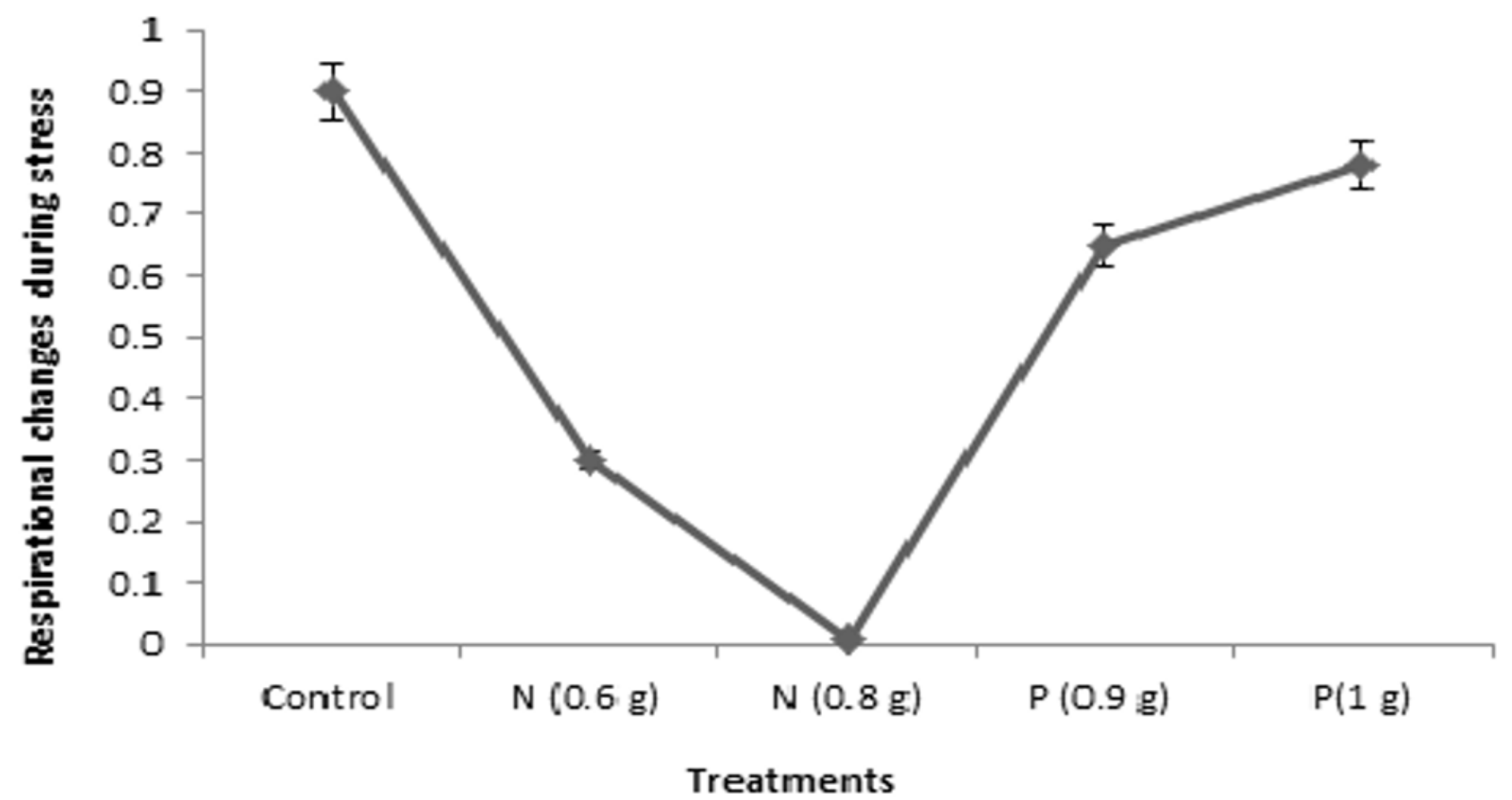

Figure 2

Effects of $N \& P$ on Respirational changes of marigold 
-Dry of flower - Dry weight of leaves

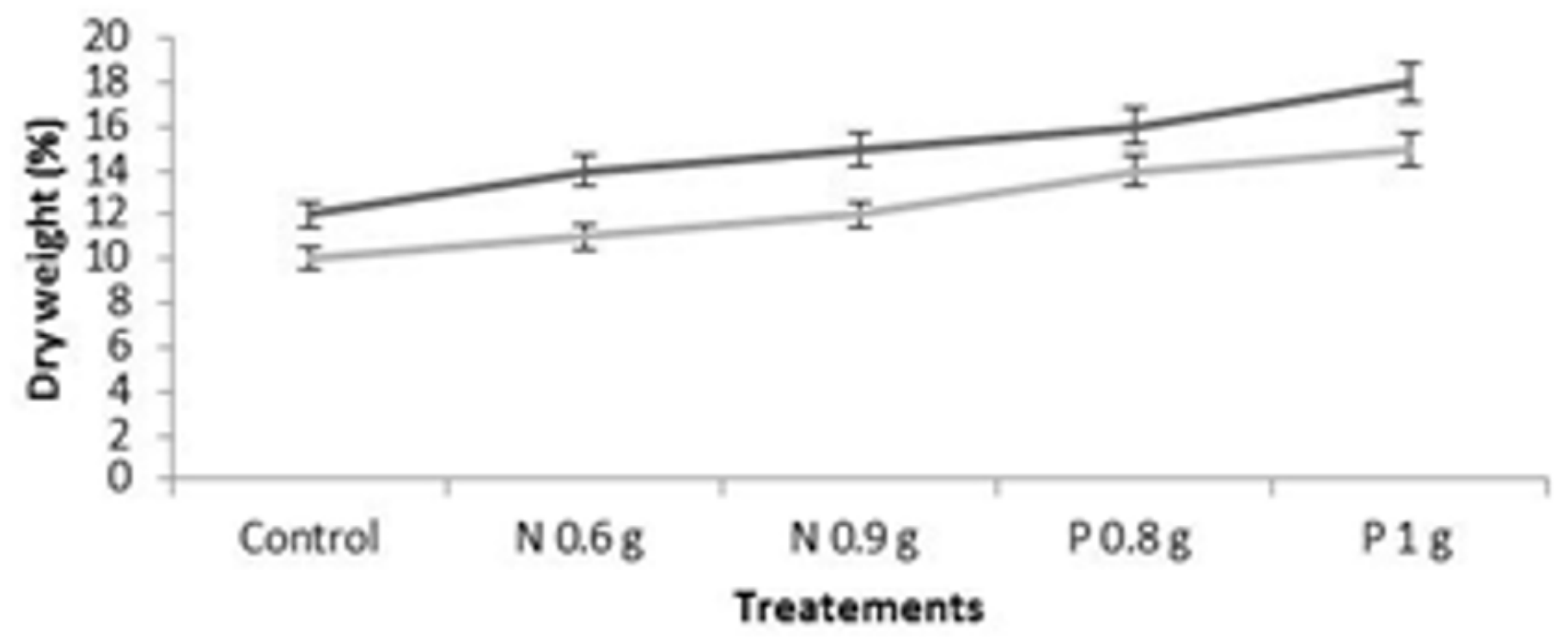

Figure 3

Dry weight of flower and Dry weight of leaves

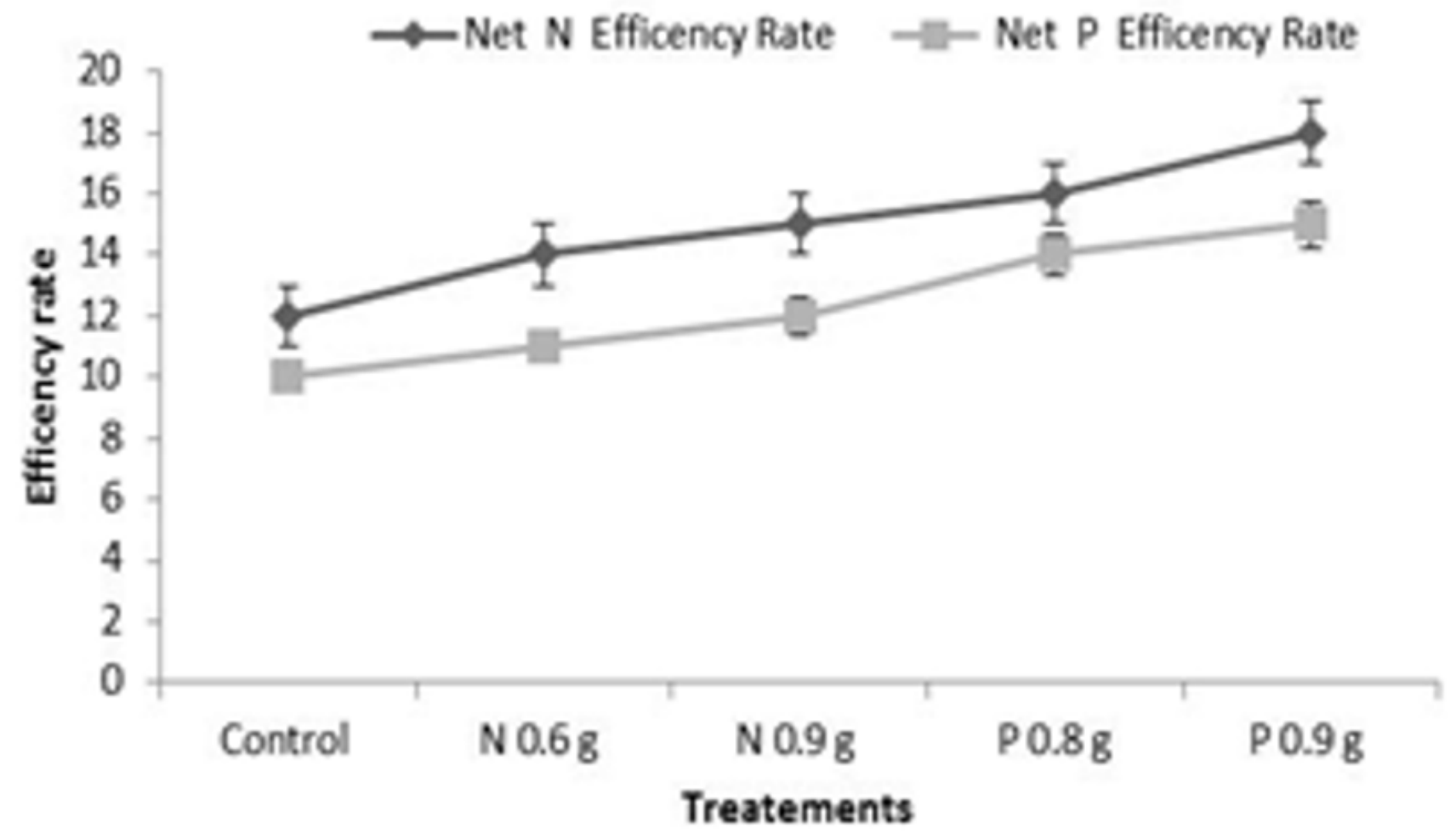

Figure 4 
Net $\mathrm{N}$ and $\mathrm{P}$ Efficiency

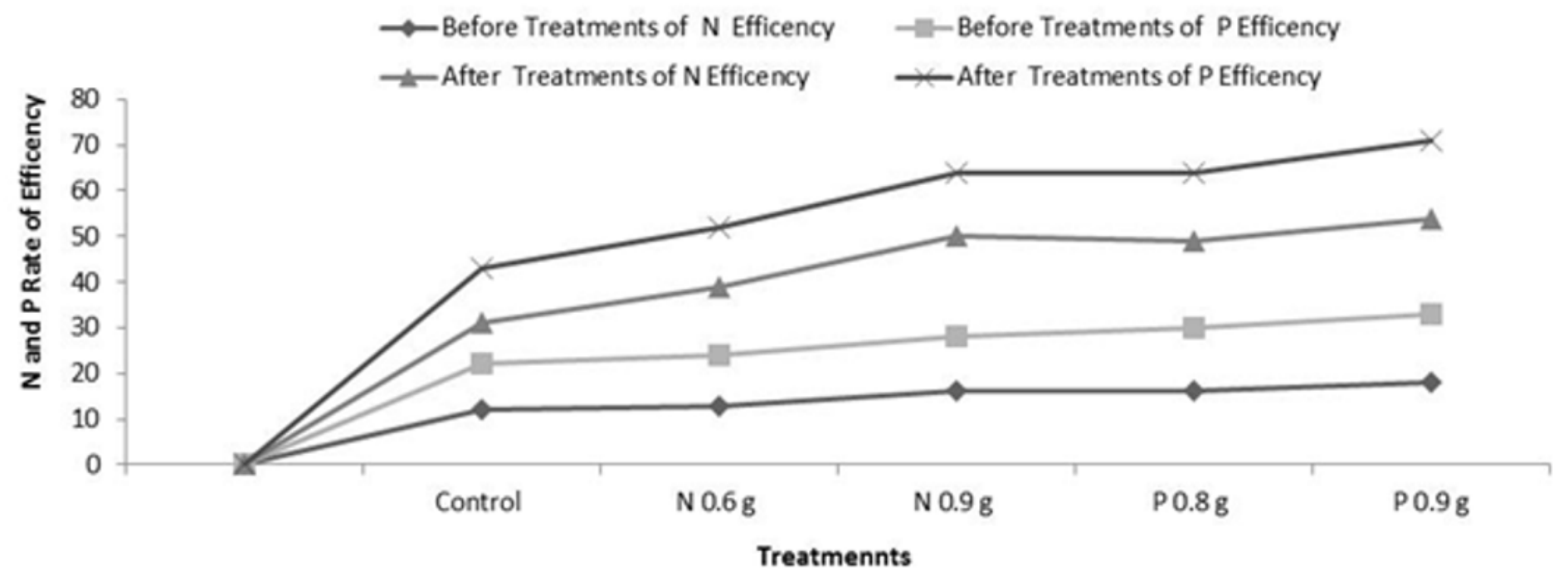

Figure 5

Calculation of $\mathrm{N}$ and $\mathrm{P}$ efficiency rates before and after sowing of marigold

- May Net $N$ Efficency Rate

- May Net P Efficency Rate

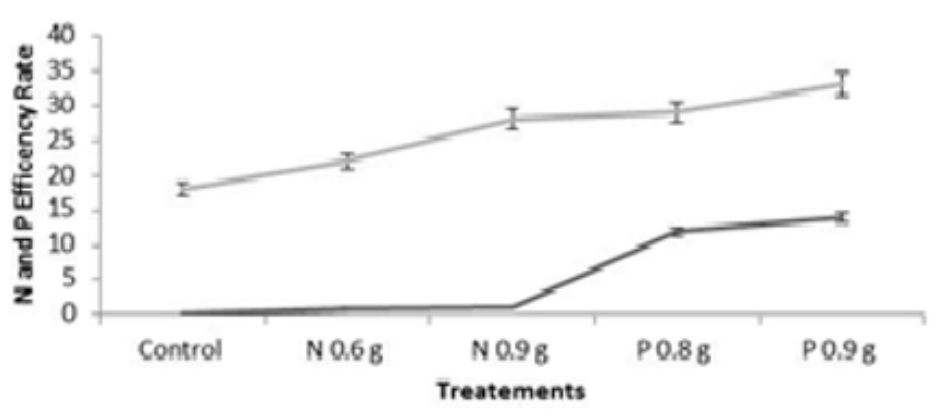

-July Net N Efficency Rate
July Net P Efficency Rate

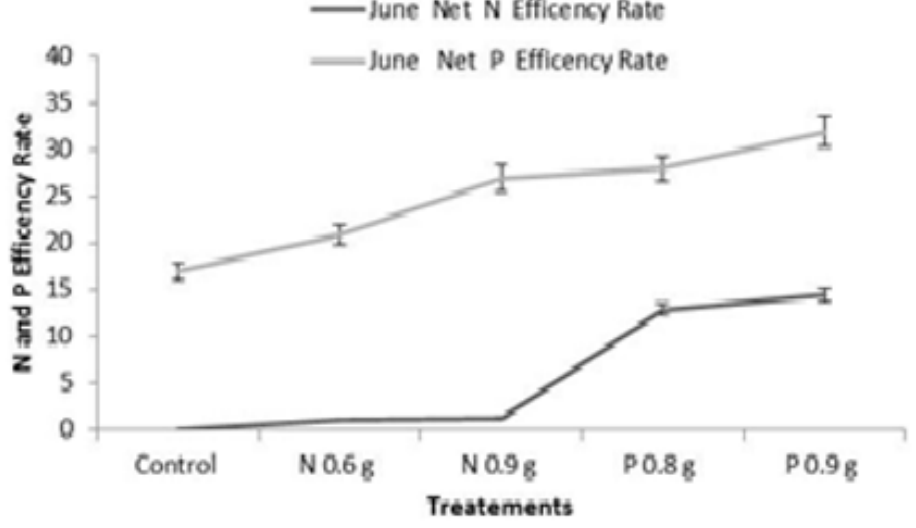

- June Net $N$ Efficency Rate

-June Net P Efficency Rate

reatement:

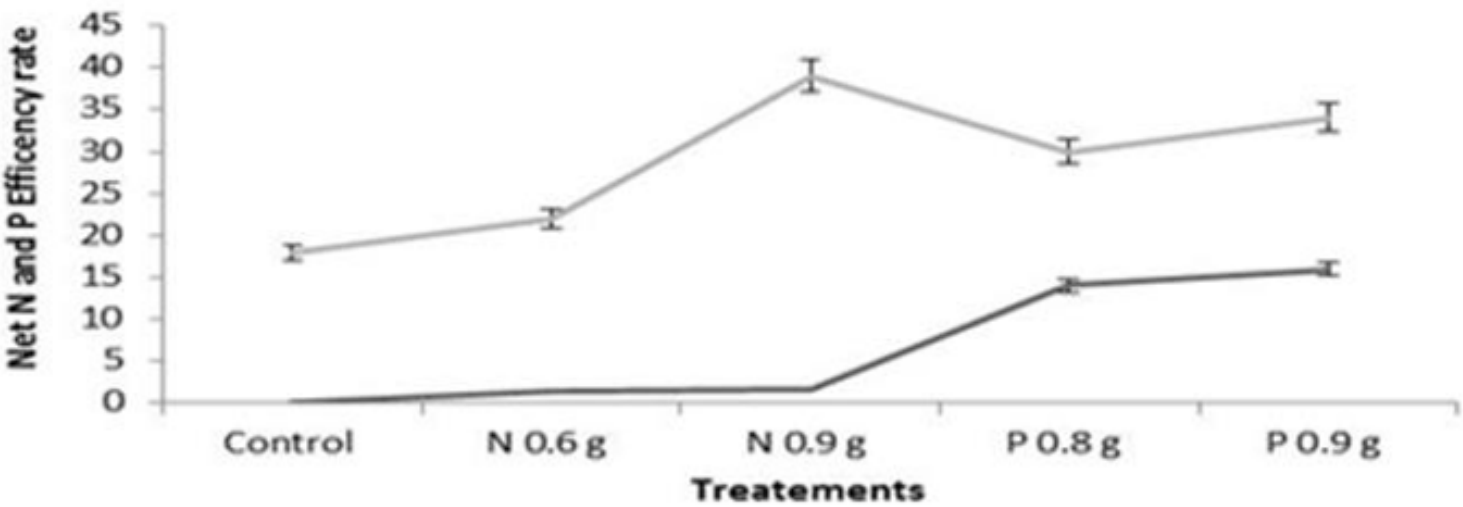

Figure 6 
Net $\mathrm{N}$ and $\mathrm{P}$ efficiency rates measured on heat stress period in months of (May, June, and July)

- June Net N Efficency Rate $=$ June Net P Efficency Rate
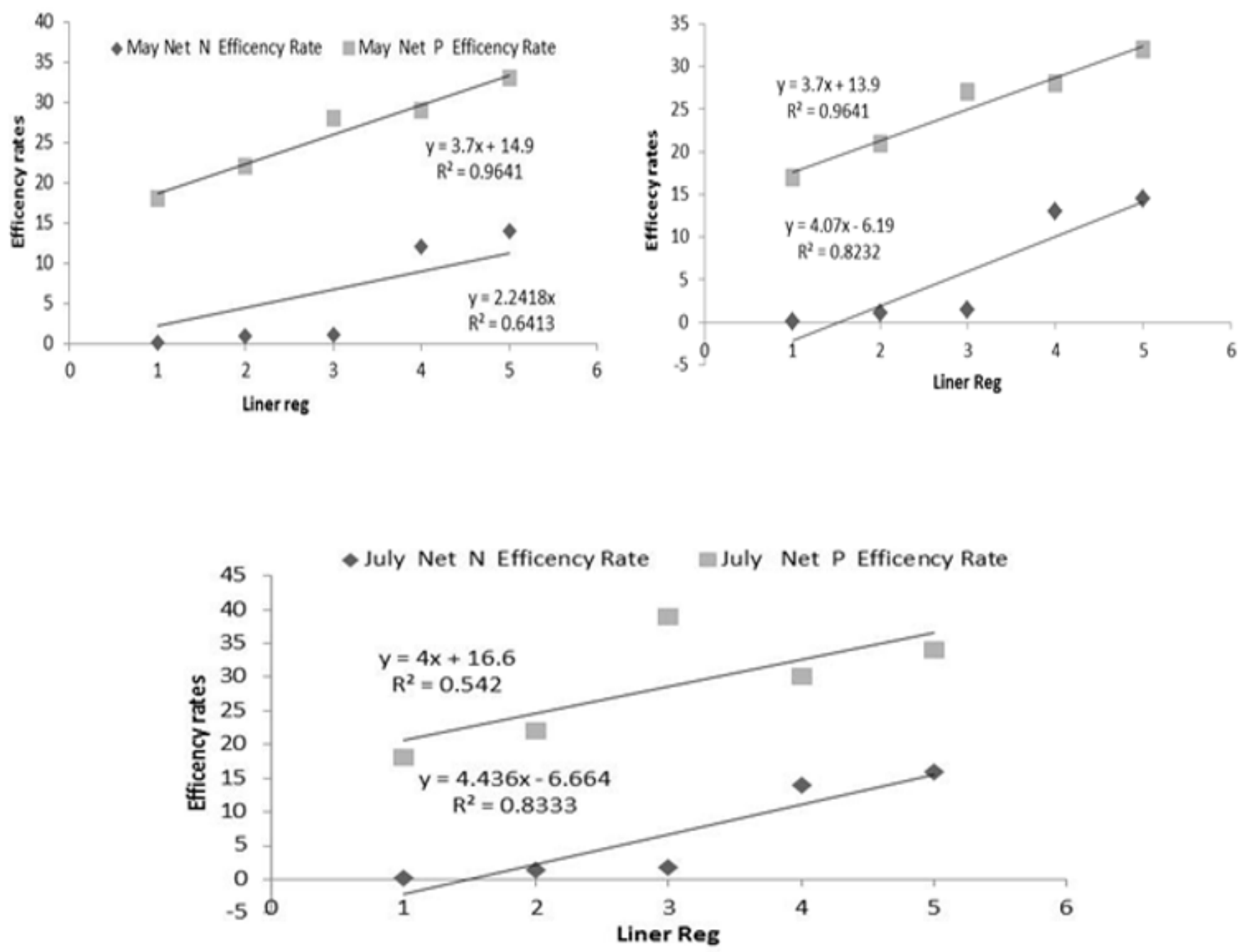

Figure 7

New model of Net $\mathrm{N}$ and $\mathrm{P}$ efficiency rates measured on heat stress period in months of (May, June, and July) 